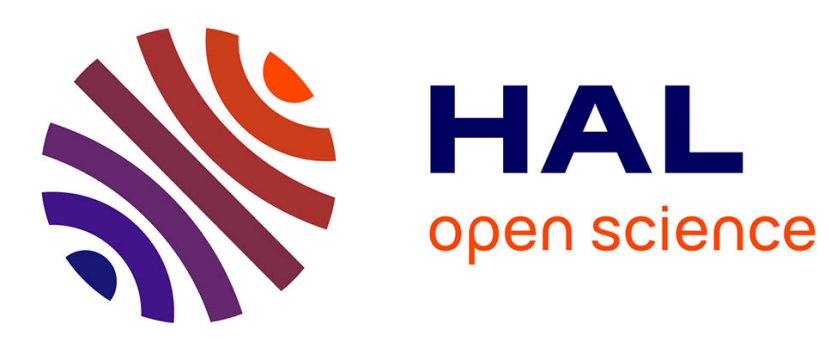

\title{
Determination of the odd part of the texture function
}

\author{
H.J. Bunge, C. Esling
}

\section{To cite this version:}

H.J. Bunge, C. Esling. Determination of the odd part of the texture function. Journal de Physique Lettres, 1979, 40 (23), pp.627-628. 10.1051/jphyslet:019790040023062700 . jpa-00231703

\section{HAL Id: jpa-00231703 https://hal.science/jpa-00231703}

Submitted on 1 Jan 1979

HAL is a multi-disciplinary open access archive for the deposit and dissemination of scientific research documents, whether they are published or not. The documents may come from teaching and research institutions in France or abroad, or from public or private research centers.
L'archive ouverte pluridisciplinaire HAL, est destinée au dépôt et à la diffusion de documents scientifiques de niveau recherche, publiés ou non, émanant des établissements d'enseignement et de recherche français ou étrangers, des laboratoires publics ou privés. 


\title{
Determination of the odd part of the texture function
}

\author{
H. J. Bunge \\ Institut fur Metallkunde und Metallphysik der TU Clausthal, F.R.G. \\ and C. Esling \\ Laboratoire de Métallurgie Structurale, Ile du Saulcy, Metz, France
}

(Reçu le 24 septembre 1979, accepté le 18 octobre 1979)

Résumé. - Lors du calcul du développement en série de la fonction de distribution des orientations (F.D.O.) à partir de figures de pôles expérimentales, seule la partie paire (rangs $l$ pair) a pu être considérée à ce jour, puisque les figures de pôles sont nécessairement centro-symétriques.

Si l'on tient compte de la condition de non-négativité de la F.D.O., et ce plus particulièrement dans les domaines nuls dans lesquels la F.D.O. prend la valeur zéro, il est également possible de déterminer la partie impaire du développement par une méthode d'approximation.

A partir de mesures d'orientations individuelles, il est également possible de déterminer les parties paires et impaires de la F.D.O.

\begin{abstract}
By calculating the series expansion of the orientation distribution function (O.D.F.) from experimental pole-figures, previously only the even part ( $l$ even) could be considered, since the pole-figures are necessarily centro-symmetric.

When the condition of non-negativity of the O.D.F. is taken into account, particularly in the null-domains in which the O.D.F. is zero, it is also possible to determine the odd part of the development by means of an approximation method.
\end{abstract}

From individual orientation measurements, it is also possible to determine the even and odd parts of the O.D.F.

The orientation distribution function (O.D.F.) of crystallites in a polycrystalline material can be represented by a series of generalized spherical harmonics :

$$
f(g)=\sum_{l=0(1)}^{\infty} \sum_{m=-l}^{+l} \sum_{n=-l}^{+l} C_{l}^{m n} T_{l}^{m n}(g) .
$$

The coefficients $C_{l}^{m n}$ can be calculated from polefigures :

$$
\tilde{P}_{\mathbf{h}}(\mathbf{y})=\frac{1}{2 \pi} \int_{[ \pm \mathbf{h} \| \mathbf{y}]}^{f(g) \mathrm{d} \gamma}
$$

The integral extends over all orientations $g$ for which the crystallographic directions $\pm \mathbf{h}$ lie in the sample direction y. From this we obtain :

$$
\begin{aligned}
P_{\mathbf{h}}(\mathbf{y})= & 4 \pi \sum_{l=0(1)}^{\infty} \sum_{m=-l}^{+l} \sum_{n=-l}^{+l} \\
& \times \frac{C_{l}^{m n}}{2 l+1}\left[k_{l}^{* m}(+\mathbf{h})+k_{l}^{* m}(-\mathbf{h})\right] k_{l}^{n}(\mathbf{y}) .
\end{aligned}
$$

Because of the relation :

$$
k_{l}^{m}(-\mathbf{h})=(-1)^{l} k_{l}^{m}(+\mathbf{h})
$$

it is not possible to calculate the coefficients with odd $l$ from polycrystalline diffraction experiments. This has recently been pointed out by $S$. Matties [1]. Therefore, all previous texture analyses have neglected the odd part. As shown by Pospiech [2] ghosts may therefore arise. If we denote by $f^{\mathbf{s}}(g)$ the part with even $l$ in relation (1) and by $f^{\mathrm{a}}(g)$ that with odd $l$ we have :

$$
f(g)=f^{\mathrm{s}}(g)+f^{\mathrm{a}}(g) .
$$

However, all previous methods based on series expansion give only the $f^{\mathrm{s}}(g)$ part.

Now, it should be noted that the pole-figures (relation 3) frequently possess null-domains $Z_{\mathrm{h}}^{0}$ in which $\widetilde{P}$ is zero. For each rotation $g$, for which any pole $+\mathbf{h}$ or $-\mathbf{h}$ falls into a domain $Z_{h}^{0}$ of the corresponding pole-figure, the orientation density $f(g)$ must be zero. 
These orientations constitute the null-domain $Z^{0}$ in the space of orientations $g$. This domain can be constructed, for instance, by the method of Imhof [4].

From relation (5), $f^{\mathrm{a}}(g)$ is known in the nulldomain :

$$
f^{\mathrm{a}}(g)=-f^{\mathrm{s}}(g) .
$$

The coefficients $C_{l}^{m n}$ of the odd part $f^{\mathrm{a}}(g)$ can be approximated by the condition :

$$
\begin{array}{r}
\int_{z_{0}}\left[-f^{\mathrm{s}}(g)-\sum_{l=1(2)}^{L} \sum_{m=-l}^{+l} \sum_{n=-l}^{+l} C_{l}^{m n} T_{l}^{m n}(g)\right]^{2} \\
\times \mathrm{d} g=\text { Min . }
\end{array}
$$

If we set :

$$
\left\{\begin{array}{l}
\int_{Z_{0}} f^{\mathrm{s}}(g) T_{\lambda}^{m n}(g) \mathrm{d} g=-a_{\lambda}^{m n} \\
\int_{Z_{0}} T_{\lambda}^{m n}(g) T_{\lambda^{\prime}}^{m^{\prime} n^{\prime}}(g) \mathrm{d} g=\alpha_{\lambda \lambda^{\prime}}^{m m^{\prime} n \prime^{\prime}}
\end{array}\right.
$$

the coefficients $C_{l}^{m n}$ for odd $l$, are obtained by solving the linear equation system :

$$
\sum_{l=1(2)}^{L} \sum_{m=-l}^{+l} \sum_{n=-l}^{+l} C_{l}^{m n} \alpha_{l l^{\prime}}^{m m^{\prime} n n^{\prime}}=a_{l^{\prime}}^{m^{\prime} n^{\prime}}
$$

The crystal directions $+\mathbf{h}$ and $-\mathbf{h}$ are indistinguishable in polycrystalline experiments, but not in individual crystal experiments. (Measurement of all the orientations $g_{\mathrm{i}}$ of individual crystallites in a polycrystal.) From the orientations $g_{i}$ of a sufficient amount of crystallites, the coefficients $C_{l}^{m n}$ can be determined from the relation $(3,5)$ :

$C_{l}^{m n}=(2 l+1) \frac{\sum_{\mathrm{i}} V_{\mathrm{i}} T_{l}^{m n}\left(g_{\mathrm{i}}\right)}{\sum_{\mathrm{i}} V_{\mathrm{i}}}(l=0(1) \ldots \infty)$.

This relation holds also for odd $l$. However, it (9) also has only been used for the determination of the even part $[5,6]$.

\section{References}

[1] Matthies, S., Phys. Status Solidi (b) 92 (1979) k 135.

[2] PosPIECH, J., communication privée.

[3] Bunge, H. J., Mathematische Methoden der Texturanalyse (Akademie-Verlag Berlin) 1969.
[4] Iмноғ,, J., Z. Metallkunde 68 (1977) 38.

[5] Bunge, H. J., Haessner, F., J. Appl. Phys. 39 (1968) 5503.

[6] Pospiech, J. et LuCKe, K., Acta Met. 23 (1975) 997. 